\title{
Water Use Efficiency in Irrigated Wheat Production Systems in Central Tunisia: A Stochastic Data Envelopment Approach
}

\author{
Ali Chebil ${ }^{1}$, Kais Abbas ${ }^{1} \&$ Aymen Frija $^{2}$ \\ ${ }^{1}$ Institut National de Recherches en Génie Rural, Eaux et Forêts (INRGREF), Tunis, Tunisia \\ ${ }^{2}$ Ecole Supérieure d'Agriculture de Mograne, Zaghouane, Tunisia \\ Correspondence: Ali Chebil, Institut National de Recherches en Génie Rural, Eaux et Forêts (INRGREF), Tunis, \\ Tunisia. Tel: 216-71-709-033, 216-71-719-630. E-mail: chebila@yahoo.es
}

Received: October 8, 2013 Accepted: November 25, 2013 Online Published: January 15, 2014

doi:10.5539/jas.v6n2p63

URL: http://dx.doi.org/10.5539/jas.v6n2p63

\begin{abstract}
This study employs stochastic data envelopment analysis (SDEA) approach for irrigation water efficiency measuring of wheat farms in an irrigated area of Chbika (Central Tunisia). Data was collected from 170 wheat farms during 2010-2011 cropping season. The empirical results show that the average water use efficiency for durum wheat irrigation, calculated using this approach was only around $41 \%$ under constant returns to scale (CRS) assumption; while it was $44 \%$ under variable returns to scale (VRS) assumption. This suggests that there is substantial scope for improving irrigation water use efficiency of wheat in the study region, using the existing technology on wheat farms. A Tobit regression was used to identify the determinants of the irrigation water use efficiency in the studied sample. Results of the Tobit analysis show a positive effect of wheat variety, irrigation source, membership in water users associations, irrigation scheduling and experience, on water use efficiency. These results are valuable for policy makers since they can be easily integrated in the national guidelines of irrigation water strategy.
\end{abstract}

Keywords: irrigation water efficiency, stochastic data envelopment analysis, Tobit model, wheat farms, Tunisia

\section{Introduction}

Tunisian agricultural production is nowadays facing to an increased water scarcity due to the growing demand of water and to the climate change. Tunisia is characterized by low rainfall and limited renewable water resources. It is influenced by the arid and semi-arid climate that covers more than $3 / 4$ of its area. The agricultural sector, which accounts for less than $12 \%$ of the gross domestic product (GDP), is highly dependent on water resources since it consumes more than $80 \%$ of total water use in the country (Al Atiri, 2009). Irrigated area in Tunisia occupies $8 \%$ of the total agricultural surface but it contributes with $35 \%$ of agricultural production, $22 \%$ of exports, and $26 \%$ of agricultural employment (ONAGRI, 2012). This performance is mainly due to the significant expansion of irrigated areas (Al-Atiri, 2009), which passed from 250,000 ha in 1990 to 450,470 ha in 2010 (MA, 2011). However, the limited water resources in the near future and the limited supply of cultivable land preclude the potential for further expansion of irrigated areas in Tunisia. In fact, fresh water mobilization has reached its limits and any further investments for water mobilization will be highly costly.

In spite of its evident scarcity, the present use of water in agriculture indicates that irrigation in Tunisia is still inefficient and much of the water used for irrigation can be saved. In fact, several farm level studies showed that irrigation water use efficiency in Tunisia is very low and ranges between $40 \%$ and $60 \%$ (Dhehibi et al., 2007; Albouchi et al., 2007; Frija et al., 2009; Naceur et al., 2010; Chemak, 2010; Chebil et al., 2012).

The improvement of water use efficiency (WUE) is vital when scarcity is considered (WANG, 2010). Water scarcity in Tunisia will become more severe as the government seeks to overcome food supply problems through the expansion of agricultural production to new lands. Additionally, industrial, domestic, touristic and environmental uses compete with agriculture for a relatively fixed volume of available water supply. WUE improvement is an essential element in attempting to mitigate water scarcity and ensure optimal irrigation water use in the agricultural sector (Frija et al., 2009). Given the large amount of water consumed by the irrigation sector in Tunisia, improving on-farm water use efficiency can contribute directly to increased water supply for other agricultural and non-agricultural uses. 
In this study, we are interested to investigate the WUE of durum wheat in central Tunisia. Wheat is a major cereal in Tunisia in terms of its output and cultivated land area. It occupies about $50 \%$ of all cereals area $(800,000$ ha on average) and represents almost $55 \%$ of the total cereals production (average wheat production is around 1.8 million tons) (MA, 2010). Irrigated wheat area in Tunisia is around 80,000ha (MA, 2011). Considering the socio-economic importance of the wheat sub-sector in Tunisia, the potential increase of IWUE should be a major concern for policy makers.

Stochastic frontier analysis (SFA) and deterministic Data Envelopment Analysis (DEA) are the most used approaches in literature to measure the irrigation water use efficiency (IWUE). From a methodological point of view, each of these methods has some advantages and disadvantages. The main advantage of the SFA approach is that the frontier is stochastic and allows the effects of noise to be separated from the effects of inefficiency (Hjalmarsson et al., 1996; Coelli et al., 2005). However, it needs a prior specification of functional form of the production function and of the distribution of the one sided error term (Coelli et al., 2005). The deterministic DEA does not require specification of the functional form but attributes all the deviations from the frontier to inefficiencies. Therefore, the later approach becomes likely to be sensitive to outliers (Coelli, 2005). The purpose of Stochastic DEA (SDEA) is to reduce the effect of extreme outliers in the data when the efficiency frontier is constructed (Land et al., 1993).

In many important situations inputs or outputs of the decision making unit (DMU) are often considered to be 'random', so technical efficiency conclusions based upon a deterministic DEA analysis can be misleading because of the high sensitivity of the efficiency scores to the levels of inputs or outputs. SDEA method has therefore been suggested to deal with these uncertainty problems (Olesen \& Petersen, 1995). The main objective of this paper is to calculate the IWUE of the durum wheat systems for central Tunisia by SDEA technique. This approach is applied for the first time in Tunisia. This application will allow us to confirm (or not) results obtained by other authors and related to the very low level of irrigation water use in different agricultural systems in Tunisia.

\section{Methodological Framework}

Efficiency can be defined as producing a maximum amount of output, given a fixed amount of inputs (Output oriented); or producing a given level of output using a minimum level of inputs (input oriented); or a mixture of both (Farrell, 1957). Efficient farms either use less input than others to produce a given quantity of output, or for a given set of inputs they generate a greater output. Hence, the production function describes a frontier (Farrell, 1957). If the production frontier is known, the technical inefficiency of any particular firm can be assessed easily by simply comparing the position of the firm relative to the frontier.

The two main approaches used to measure efficiency are DEA deterministic and SFA (Coelli, 1995). The later model appends an error term, assuming two components: one is symmetric, capturing statistical noise and random shocks, and the other is one-sided, representing technical inefficiency effects. By far the most serious impediment to a wider acceptance of DEA as a valid analytical method in economy is that it is does not distinguish inefficiency from random shock. One has to specify the appropriate DEA model in order to obtain a proper measurement of the efficiency of a farm (Land et al, 1993; Olesen \& Petersen, 1995; Seiford, 1996). Following Land et al. (1993), we assume that input values are deterministic, so that only the outputs are to be represented as random variables.

Recently, some advances in sub-vector efficiency calculation from the DEA models and from the stochastic frontier production have been achieved. The sub-vector efficiency measurement looks at the possible reduction in a selected subset of inputs while holding all the other inputs and outputs constant (Färe et al., 1994; Oude Lansink et al., 2002; Oude Lansink \& Silva, 2004; Speelman et al., 2008). The main features of the conventional and SDEA to analyze the subvector efficiencies of inputs are described below. In this study we also opt for this assumption because in agricultural production increasing the inputs does not usually result in a proportional increase in output (Speelman et al., 2008)

\subsection{Stochastic DEA Approach of Water Use Efficiency Calculation}

\subsubsection{Deterministic DEA Model}

Mathematically, the input-oriented DEA model can be written as follows (See Färe et al., 1994; Oude Lansink \& Silva, 2004; Lilienfeld \& Asmild, 2007; Speelman et al., 2008; Frija, 2009) for more details about standard DEA subvector efficiency models): 


$$
\begin{gathered}
\operatorname{Min}_{\theta, \lambda} \theta^{S} \\
\text { s.t. } \sum_{k=1}^{K} \lambda_{k} y_{m, k} \geq y_{m, o} \\
\sum_{k=1}^{K} \lambda_{k} x_{s, k} \leq \theta^{s} . x_{s, o} \\
\sum_{k=1}^{K} \lambda_{k} x_{n-s, k} \leq x_{n, o} \\
\sum_{k=1}^{K} \lambda_{k}=1 \\
\lambda_{k} \geq 0
\end{gathered}
$$

The $\theta^{S}$ in the resulting subvector model is the IWUE score of each farm. $\lambda_{k}$ is a vector of $\mathrm{k}$ elements representing the contribution of each farm in determining the technical efficiency of the farm under consideration $\left(\mathrm{farm}_{0}\right) ; x_{n 0}$ and $y_{m 0}$ are, respectively, the input and the output vectors of $\operatorname{farm}_{0}$. For more information about the use of a subvector-DEA model for the calculation of IWUE see e.g. Lilienfeld and Asmild (2007), Speelman et al. (2008) and Frija et al. (2009). The IWUE score can be calculated for a given farm by looking at the possible reduction in the water use holding all other inputs and outputs constant.

\subsubsection{Stochastic DEA Model}

Following Land et al. (1993), we assume that input values are deterministic, so that only the outputs are to be represented as random variables with a normal distribution. This allows the constraints to hold with the probability level $(1-\alpha)$. Hence, the SDEA for model (1) can be formulated as:

$$
\begin{gathered}
\operatorname{Min}_{\theta, \lambda} \theta^{S} \\
\text { s.t. } \operatorname{Pr}\left\{\sum_{k=1}^{K} \lambda_{k} y_{m, k} \geq y_{m, o}\right\} \geq(1-\alpha) \\
\sum_{k=1}^{K} \lambda_{k} x_{s, k} \leq \theta^{S} . x_{s, o} \\
\sum_{k=1}^{K} \lambda_{k} x_{n-s, k} \leq x_{n, o} \\
\sum_{k=1}^{K} \lambda_{k}=1 \\
\lambda_{k} \geq 0
\end{gathered}
$$

Where $\operatorname{Pr}$ means "probability" and $\alpha$ is a predetermined scalar between 0 and 1 .We set $\alpha$ at the conventional level of 0.05 .

At this point, assume that each output $\mathrm{y}_{\mathrm{k}}$ is normally distributed with a mean $\mu_{\mathrm{k}}$ and a variance $\sigma_{k}^{2}$. Further assume that $\operatorname{Cov}\left(\mathrm{y}_{\mathrm{j}}, \mathrm{y}_{\mathrm{k}}\right)=0$. Now, we define the random variable as:

$$
u=\sum_{k=1}^{K} \lambda_{k} y_{k}-y_{0}
$$


Then,

$$
E(u)=\sum_{k=1}^{K} \lambda_{k} u_{k}-u_{0}=u_{u}
$$

And

$$
\operatorname{Var}(u)=\sum_{k=1, k \neq 0}^{K} \lambda_{k}^{2} \sigma_{k}^{2}+\left(\lambda_{k}-1\right)^{2} \sigma_{o}^{2}=\sigma_{u}^{2}
$$

The random variable representing the output shortfall is normally distributed because the $\mathrm{y}_{\mathrm{k}}$ 's has the normal distribution:

$$
z=\frac{u-u_{u}}{\sigma_{u}}
$$

Hence

$$
\operatorname{Pr}\left\{\sum_{k=1}^{K} \lambda_{k} y_{k} \geq y_{o}\right\}=\operatorname{Pr}\{u>0\}=\operatorname{Pr}\left\{z \geq \frac{-u}{\sigma_{u}}\right\}
$$

But, because of symmetry property of the normal distribution

$$
\operatorname{Pr}\left\{z \geq \frac{-u}{\sigma_{u}}\right\}=\operatorname{Pr}\left\{z \leq \frac{u}{\sigma_{u}}\right\}=\Phi\left(\frac{u}{\sigma_{u}}\right)
$$

Where $\Phi$ represent the cumulative distribution function of the standard normal variable. Consequently, the probability statement for the typical output constraint can be replaced by the equivalent restriction

$$
\Phi\left(\frac{u}{\sigma_{u}}\right) \geq(1-\alpha)
$$

\subsection{Tobit Model}

This study uses the Tobit model to analyze the role of farm attributes in explaining 'IWUE'. This approach has been widely used in the efficiency studies (Speelman et al., 2008; Naceur et al., 2010; Chebil et al., 2012). In fact, the values of the dependent variable (i.e., IWUE scores) lie in the interval $(0,1)$. The censored Tobit model can be then used to get consistent estimation of parameters. Tobit model used in our study is specified as follows:

$$
I W U E_{i}=\left\{\begin{array}{l}
I W U E_{i}^{*} \text { if } 0<I W U E^{*}<1 \\
0 \quad \text { if IWUE }{ }^{*} \leq 0 \\
1 \quad \text { if } I W U E^{*} \geq 1
\end{array}\right.
$$

Where IWUE $\mathrm{i}_{\mathrm{i}}$ the observed dependent variable (IWUE) for the ith farm; $\mathrm{IWUE}_{\mathrm{i}}{ }^{*}$ is a unobserved latent (hidden) variable for the ith IWUE farm that is observed for values greater than 0 and censored for values less than or equal to 1 .

$$
I W U E^{*}=X_{i} \beta+\varepsilon_{i}
$$

Where $X_{i}$ is a vector of independent variables which is supposed to influence the efficiency. The $\beta$ 's are parameters associated with the independent variables to be estimated. The $\varepsilon$ is the independently distributed error term and is assumed to be normally distributed with a mean of zero and a constant variance $N\left(0, \sigma^{2}\right)$. Since the dependent variable of IWUE varies between 0 and 1, Least Ordinary Square (LOS) would produce biased and inconsistent estimates (Maddala, 1983). Therefore, the maximum likelihood estimation is recommended in the Tobit analysis. 


\subsection{Data and Variables Definitions}

The data employed in this study consists of information about the production structure of 170 Tunisian wheat farms. In order to ensure homogeneity in land and weather conditions, the farms in the sample have been chosen from Chbika region situated in Kairouan province (latitude $35^{\circ} 40^{\prime} \mathrm{N}$, longitude $10^{\circ} 06 \mathrm{E}$, altitude $60 \mathrm{~m}$ ) which is located in the center of Tunisia. Chbika is facing growing problems of water scarcity. It is located in the semi-arid bioclimatic lower floor and characterised by moderate winter. It has an annual average rainfall of $304 \mathrm{~mm}$ with a coefficient of variation of 0.39 (Henia, 1993). The average temperature of the region is about $19.6^{\circ} \mathrm{C}$. High temperatures occur in summer. During 2011 , the max temperature is $40^{\circ} \mathrm{C}$ in July and the min temperature is $3.97^{\circ} \mathrm{C}$ in January $(\mathrm{CTV}, 2012)$.

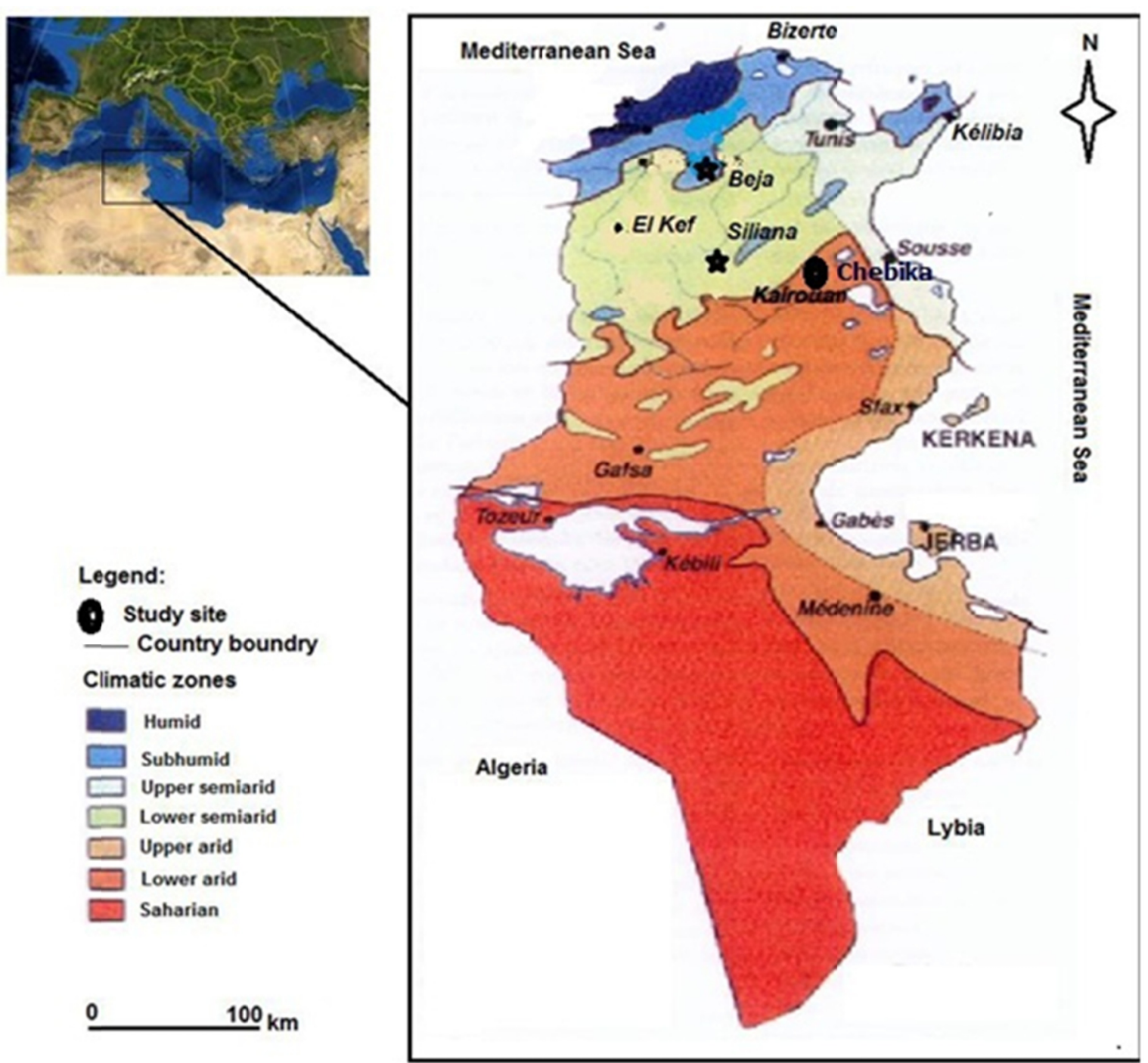

Figure 1. Map of Tunisia showing the study region

The main crops cultivated in the area are wheat, vegetables, fodder and olive. The irrigated cereal area of this region is around 4500 ha. The number of farmers in irrigated area is about 1000 (CTV, 2012). Groundwater represents the main water source. The data used in the study was collected in 2011 with the collaboration of the extension service in the region, through a questionnaire to cereal-growing farmers.

Wheat production value per ha is used as output of the subvector efficiency model described in the previous section. In addition, three inputs (labour, water and fertilizers) are included in the estimation of the SDEA model. Table 1 presents a summary statistics of output and inputs data used for our case study. As it can be seen, the average annual production value of wheat in the study area is around 2226.26 Tunisian National Dinar (TND) per 
ha farm ranging from a minimum of 1016 to a high of $4370 \mathrm{TND} / \mathrm{ha}$. The standard deviation of the water input vector indicates a large variability of the irrigation volume among the farms.

Table 1. Summary statistics of the sample variables

\begin{tabular}{llllll}
\hline Variable & & Mean & Standard Deviation & Min & Max \\
\hline Output & Production value (TND/ha) & 2226.26 & 636.46 & 1016 & 4370 \\
Inputs & Water (m3/ha) & 2696.24 & 1110.80 & 500 & 4500 \\
& Labor expenses (TND/ha) & 66.46 & 22.30 & 31.50 & 178.75 \\
& Fertilizer expenses (TND/ha) & 142.23 & 60.02 & 33 & 338 \\
\hline
\end{tabular}

$1 \mathrm{TND} \approx 0 . \overline{70 \text { US\$. }}$

The empirical Tobit regression model takes the following form:

$$
I W U E^{*}=\alpha_{0}+\alpha_{1} A G E+\alpha_{2} E L+\alpha_{3} E X P+\alpha_{4} S I Z E+\alpha_{5} W S+\alpha_{6} G D A+\alpha_{7} I R R+\alpha_{8} V A R+\alpha_{9} P E S+\varepsilon_{i}
$$

where:

IWUE (Dependent variable): Irrigation water use efficiency scores.

The independent variables are :

AGE $=$ age (in years);

EL (Education level) $=1$ if farmer has more or equal than secondary level, 0 otherwise;

$\mathrm{EXP}=$ farming experience (in years);

SIZE $=$ Farm size (in ha);

WS (water source) $=1$ if the farmer uses 2 sources, 0 if one source;

GDA (membership in a water users association) $=1$ if farmer is member of a water user association, 0 if not

IRR (Irrigation management) $=1$ if farmer respect the critical period of irrigation, 0 if not

VAR (wheat variety cultivated) $=1$ if farmer uses Maali variety, 0 if not (Maali variety is known to be among the most productive varieties in Tunisia and is highly promoted by policy makers)

PES (pesticide) $=1$ if farmer uses pesticide during the crop cycle, 0 if not.

\section{Results and Discussion}

\subsection{Efficiency Scores}

SDEA model is estimated using the GAMS (General Algebraic Modelling System) program. Table 2 presents the frequency distributions of overall technical efficiency and irrigation water use efficiency scores of the 170 farms considered in our study.

The mean farms technical efficiencies estimated under CRS and VRS assumptions are respectively 0.70 and 0.62 . This implies that the current level of output can be produced using 30\% less inputs on average. The difference between the VRS and CRS measures indicate that many farmers are not operating at an efficient scale (SE).

The SE $\left(\theta^{\mathrm{CRS}} / \theta^{\mathrm{VRS}}\right)$ is equal to 0.89 . The SDEA results however reveal a wide variation in individual efficiency scores across farms. These scores are ranging from $35.6 \% \%$ to $100 \%$ under VRS and from $27 \%$ to $100 \%$ under CRS.

The average IWUE of our farm sample was about 0.44 under VRS and 0.41 under CRS. Farmers are then less efficient in the use of water compared to the use of other inputs. This indicates that an increase in the efficiency of water use will results in a better overall efficiency. A large range of water efficiencies are observed across 170 farms. As showed in table 2 below, there are 129 farms with IWUE scores below 50\%, 25 farms between 50-75\%, and 16 farms with scores more than $75 \%$ under VRS. This result suggests that wheat farms may reduce their water use level while maintaining the same level of production. This result is consistent with previous studies in Tunisia (Dhehibi et al., 2007; Albouchi et al., 2007; Frija et al., 2009; Chemak et al., 2010; Naceur et al., 2010; Chebil et al., 2012). Empirical studies have also used a deterministic approach to measure water use efficiency. However, in the present study, SDEA was used in order to assess these IWUE scores. 
Table 2. Frequency distribution of efficiency ratings of wheat farms in Chbika

\begin{tabular}{lllllllll}
\hline \multicolumn{3}{l}{ Technical efficiency (TE) } & \multicolumn{5}{c}{ IWUE } \\
\hline \multicolumn{3}{c}{ CRS } & \multicolumn{3}{c}{ VRS } & CRS & \multicolumn{3}{l}{ VRS } \\
\hline $\begin{array}{l}\text { Scores } \\
\text { of farms }\end{array}$ & $\begin{array}{l}\text { Percentage } \\
\text { of farms }\end{array}$ & $\begin{array}{l}\text { Number } \\
\text { of farms }\end{array}$ & $\begin{array}{l}\text { Percentage } \\
\text { of farms }\end{array}$ & $\begin{array}{l}\text { Number } \\
\text { of farms }\end{array}$ & $\begin{array}{l}\text { Percentage } \\
\text { of farms }\end{array}$ & $\begin{array}{l}\text { Number } \\
\text { of farms }\end{array}$ & $\begin{array}{l}\text { Percentage } \\
\text { of farms }\end{array}$ \\
$0.25-0.50$ & 38 & 22.40 & 11 & 6.50 & 81 & 47.65 & 91 & 54.53 \\
$0.5-0.75$ & 105 & 61.80 & 109 & 64.10 & 35 & 20.59 & 25 & 14.71. \\
$>0.75$ & 27 & 15.90 & 50 & 29.40 & 19 & 11.18 & 16 & 09.41 \\
Average & 0.62 & & 0.70 & & 0.41 & & 0.44 & \\
Min & 0.27 & & 0.36 & & 0.12 & & 0.11 & \\
Max & 1 & & 1 & & 1 & & 1 & \\
\hline
\end{tabular}

\subsection{Factors Explaining Efficiencies of Water Use}

Tobit regression explaining efficiency, as defined in equation 10 is estimated using Eview (econometric views) package version 5. The results of the Tobit model estimation by Likelihood are listed in Table 3.

Table 3. Tobit estimation results of factors affecting IWUE

\begin{tabular}{llllll}
\hline & Impact hypothesis & VRS & \multicolumn{3}{l}{ CRS } \\
\hline Variables & & Coefficient & Z-Statistic & Coefficient & Z-Statistic \\
\hline AGE & $(-)$ & -0.001 & -0.947 & -0.002 & -1.555 \\
EL & $(+)$ & -0.027 & -0.698 & -0.033 & -0.920 \\
EXP & $(+)$ & 0.004 & $2.742^{*}$ & 0.003 & $2.438^{*}$ \\
SIZE & $(+)$ & 0.002 & 1.214 & 0.001 & 1.213 \\
WS & $(+)$ & 0.357 & $4.175^{*}$ & 0.356 & $4.646^{*}$ \\
GDA & $(+)$ & 0.103 & $2.755^{*}$ & 0.094 & $2.747^{*}$ \\
IRR & $(+)$ & 0.162 & $4.094^{*}$ & 0.162 & $4.430^{*}$ \\
VAR & $(+)$ & 0.169 & $4.337^{*}$ & 0.152 & $4.204^{*}$ \\
PES & $(+)$ & -0.012 & -0.326 & -0.013 & -0.365 \\
C & & 0.221 & $2.937^{*}$ & 0.263 & $3.769^{*}$ \\
LR $^{\text {Note }}$ & & $66.80^{*}$ & & $70.22^{*}$ & \\
\hline
\end{tabular}

* Significant at the $5 \%$ level.

Regarding the Tobit model results, the likelihood test rejects a null hypothesis that all slope parameters are simultaneously null. This confirms that Tobit model is statistically significant. The majority of the estimated coefficients are significant at $5 \%$. Furthermore, the estimated Tobit model indicates the positive effect of variety choice, irrigation sources, membership in water users association, irrigation management and experience on water use efficiency.

Finally, based on the empirical results, some suggestions such as encouraging farmers' association, dissemination and encouragement of the use of adapted durum wheat varieties to the region, setting up training programs on irrigation scheduling and improvement of extension services are needed in order to increase the WUE in the region.

Moreover, this study confirms the previous results regarding the weak level of irrigation water use efficiency in Tunisia, which were obtained using standard DEA approach or stochastic production function approach (Frija et al., 2009; Dhehibi et al., 2007). It is obvious that the use of this rare resource in Tunisia has to move toward a more 
economic and saving approach. In addition to appropriate policies and strategies, innovative technologies for irrigation water saving will absolutely have to be further promoted in Tunisia in Future.

\section{Conclusions}

This study aims to measure the irrigation water use efficiency of a sample of wheat farms, located in central semi-arid Tunisia, and to identify its determinants. The stochastic data envelopment analysis was estimated based on data collected from 170 randomly selected farms for the 2010-2011 production season. The survey was conducted in Chbika region situated in the governorate of Kairouan.

The average technical efficiencies estimated under the constant returns to scale and variable returns to scale hypothesis of the farms in the sample are 0.70 and 0.62 . This implies that the current level of output can be produced using $30 \%$ less inputs, on average. The average irrigation water use efficiency is about 0.44 under variable returns to scale and 0.41 under constant returns to scale. It seems that substantial decreases in water use could be attained by using the existing irrigation technology on wheat farms. This result is consistent with previous studies in Tunisia (Dhehibi et al., 2007; Albouchi et al., 2007, Frija et al., 2009; Chemak et al., 2010; Naceur et al., 2010; Chebil et al., 2012). Empirical studies listed above have also used deterministic approach to measure water use efficiency. However, in the present study, stochastic data envelopment analysis was used in order to assess these irrigation water use efficiency scores. Results of the Tobit analysis show the positive effect on water use efficiency of variety choices, irrigation sources, membership in water users associations, irrigation management and experience. These results are valuable for policy makers since they can be easily integrated in the general guidelines of water valorisation policies

Finally, irrigation water use efficiency was found by many studies in Tunisia to be very low compared to the important efforts made by the government in order to save water. Even though, we tried to use a more comprehensive methodology in this paper, which is unique application in the Tunisian context, results about irrigation water use efficiency scores were still found to be very low. Thus, different methodologies are confirming the same results about inefficiency of irrigation water use.

\section{Acknowledgments}

This work was done in the framework of the project "Enhancing Food Security in Arab Countries" coordinated by ICARDA. We gratefully acknowledge the financial support from the Arab Fund for Economic and Social Development (AFES), Islamic Development Bank (IDB), and Kuwait Fund for Arab Economic Development (KFAED), and OPEC Fund for International Development.

\section{References}

Al Atiri, R. (2009). Politique du pays en matière de gestion de l'eau. Journée nationale de l'économie d'eau. INAT, 22 Mars, Tunis.

Albouchi, L., Bachta, M. S., \& Jacquet, F. (2007). Compared production efficiency in irrigated areas within a watershed. New Medit, VI(3), 4-13.

Cellule Technique de Vulgarisation (CTV). (2012). Rapport d'activités annuel. Kairouan.

Chebil A., Frija, A., \& Abdelkafi, B. (2012). Irrigation water use efficiency in collective irrigated schemes of Tunisia: determinants and potential irrigation cost reduction. Agricultural Economic Review, 13(1), 39-48.

Chemak, F., Boussemart, J. P., \& Jacquet, F. (2010). Farming system performance and water use efficiency in the Tunisian semi-arid: data envelopement analysis. International Transactions in operational research, 17, 381-396. http://dx.doi.org/10.1111/j.1475-3995.2009.00736.x

Coelli, T. (1995). Recent Developments in Frontier Modelling and Efficiency Measurement. Australian Journal of Agricultural Economics, 39(3), 219-45. http://dx.doi.org/10.1111/j.1467-8489.1995.tb00552.x

Coelli, T., Rao, D., O’Donnell, C., \& Battese, G. (2005). An Introduction to Efficiency and Productivity Analysis (2nd ed.). New York, NY: Springer.

Dhehibi, B., Lachaal, L., Elloumi, M., \& Messaoud, A. (2007). Measuring irrigation water use efficiency using stochastic production frontier: An application on citrus producing farms in Tunisia. African Journal of Agricultural and Resource Economics, 2, 99-114.

Färe, R., Grosskopf, S., \& Lovell, C. A. K. (1994). Production Frontiers. Cambridge: Cambridge University Press. 
Frija, A., Chebil, A., Speelman, S., Buysse, J., \& Van Huylenbroeck, G. (2009). Water use and technical efficiencies in horticultural greenhouses in Tunisia. Agricultural Water Management, 96(11), 1509-1516. http://dx.doi.org/10.1016/j.agwat.2009.05.006

Hénia, L. (1993). Climat et bilan de l'eau en Tunisie. Essai de régionalisation climatique par les bilans hydriques. Faculté des sciences humaines et sociales de Tunis, Publication de l'Université de Tunis I, Vol. XXVI., Deuxième série géographiques. http://dx.doi.org/10.1007/BF00157046

Hjalmarsson, L., Kumbhakar, S., \& Heshmati, A. (1996). DEA, DFA and SFA: A Comparison. The Journal of Productivity Analysis, 7, 303-327.

Land, K. C., Lovell, A. A. K., \& Thore, S. (1993). Chance-Constrained Data Envelopment Analysis. Managerial and Decision Economics, 14, 541-554. http://dx.doi.org/10.1002/mde.4090140607

Lilienfeld, A., \& Asmild, M. (2007). Estimation of excess water use in irrigated agriculture: a data envelopment $\begin{array}{lllll}\text { analysis approach. Agricultural Water } & \text { Management, } & \text { 94, }\end{array}$ http://dx.doi.org/10.1016/j.agwat.2007.08.005

Maddala, G. S. (1983). Limited dependent and qualitative variables in econometrics. Cambridge: Cambridge University Press. http://dx.doi.org/10.1017/CBO9780511810176

Ministère de l'Agriculture (MA). ( 2010). Annuaire des statistiques agricoles. Tunisie.

Ministère de l'Agriculture (MA). ( 2011). Enquête sur les périmètres irrigués. Tunisie.

Naceur, M., Sghaier, M., \& Bachta, M. S. (2010). Water Use and Technical Efficiencies in Private Irrigated Perimeters in Zeuss-Koutine Watershed, South-Eastern Tunisia, BALWOIS 2010 - Ohrid, Republic of Macedonia - 25, 29 May 2010.

Olesen, O. B., \& Petersen, N. C. (1995). Chance constrained efficiency evaluation. Management Science, 41, 442-457. http://dx.doi.org/10.1287/mnsc.41.3.442

ONAGRI (Observatoire National de l'Agriculture). (2012). Rapport d'activités. Ministère de l'Agriculture.

Oude Lansink, A., \& Silva, E. (2004). Non-parametric production analysis of pesticides use in the Netherlands. Journal of productivity analysis, 21, 49-65. http://dx.doi.org/10.1023/B:PROD.0000012452.97645.30

Oude Lansink, A., Pietola, K., \& Bäckman, S. (2002). Efficiency and productivity of conventional and organic farms in Finland 1994-1997. European Review of Agricultural Economics, 29(1), 51-65. http://dx.doi.org/10.1093/erae/29.1.51

Seiford, L. M. (1996). Data Envelopment Analysis: The evolution of the state of the art (1978-1995). Journal of Productivity Analysis, 7, 99-138. http://dx.doi.org/10.1007/BF00157037

Speelman, S., D'Haese, M., Buysse, J., \& D'Haese, L. (2008). A measure for the efficiency of water use and its determinants, a case study of small-scale irrigation schemes in North-West Province, South Africa. Agricultural Systems, 98, 31-39. http://dx.doi.org/10.1016/j.agsy.2008.03.006

WANG, X. ( 2010). Irrigation Water Use Efficiency of Farmers and Its Determinants: Evidence from a Survey in Northwestern China. Agricultural Sciences in China, 9(9), 1326-1337. http://dx.doi.org/10.1016/S1671-2927(09)60223-6

\section{Note}

$L R=-2\left(\log L_{r}-\log L_{u}\right)$ where $\log \mathrm{L}_{\mathrm{u}}$ is the $\log$-likelihood for the unrestricted model and $\log \mathrm{L}_{\mathrm{r}}$ is the log-likelihood for the model with $\mathrm{p}$ parameters restrictions imposed. The likelihood ratio statistic follows a chi-square distribution with $\mathrm{p}$ degrees of freedom.

\section{Copyrights}

Copyright for this article is retained by the author(s), with first publication rights granted to the journal.

This is an open-access article distributed under the terms and conditions of the Creative Commons Attribution license (http://creativecommons.org/licenses/by/3.0/). 